\title{
Poziom wiedzy na temat raka szyjki macicy wśród kobiet
}

\section{The level of knowledge on cervical cancer among women}

\author{
PAULA JANKOWSKA ${ }^{1}$, MARZENA KIKOLSKA ${ }^{1}$, MARTYNA \\ KWIATKOWSKA ${ }^{1}$, DOROTA KOCHMAN ${ }^{2}$, MARIOLA GŁOWACKA ${ }^{2}$ \\ ${ }^{1}$ Studenckie Koło Naukowe Pielęgniarstwa Klinicznego, Wydział Nauk o Zdrowiu PWSZ \\ w Płocku \\ ${ }^{2}$ Wydział Nauk o Zdrowiu PWSZ w Płocku
}

DOI: http://dx.doi.org/10.21784//wP.2017.002

ISSN: 2451-1846

\section{Streszczenie:}

Wstęp. Umieralność na raka szyjki macicy w Polsce stanowi jeden z głównych problemów onkologicznych.

Cel. Ocena wiedzy kobiet na temat czynników ryzyka rozwoju raka szyjki macicy oraz możliwości zapobiegania nowotworowi poprzez badania profilaktyczne.

Materiał i metody. Badanie zostało przeprowadzone w Internecie. W badaniu wzięło udział 135 kobiet. Posłużono się narzędziem badawczym - kwestionariuszem ankiety, zawierającym 20 pytań dotyczących przedmiotu badań. Informacje zebrane w 135 kwestionariuszach ankiet poddano analizie. Na podstawie uzyskanych informacji zostały stworzone tabele statystyczne i wykresy obrazujące rozkłady analizowanych cech. Badane kobiety wyraziły zgodę i chęć udziału w badaniach oraz zostały poinformowane o anonimowości badania.

Wyniki. W przeprowadzonym badaniu 74\% kobiet uważa, że badanie cytologiczne jest najlepszą metodą pozwalającą wykryć wszelkie nieprawidłowości. Najwięcej badanych, które tak zadeklarowało było w wieku 21-30 i 41-50. Aż 39\% kobiet nigdy nie było badanych pod kątem 
wczesnego wykrywania raka szyjki macicy i $12 \%$ nie pamięta kiedy miało to badanie. Niecała połowa (42\%) miała w ciągu ostatnich 3 lat pobierany wymaz cytologiczny a około 7\% kobiet miało wciągu ostatnich 3-5 lat. Połowa kobiet wie $\mathrm{z}$ jaką częstotliwością należy wykonywać cytologię, niestety druga połowa nie wie tego. Jako źródło informacji odnośnie raka szyjki macicy wskazywano lekarza lub położną(26\%), połowa badanych kobiet $(52 \%)$ czerpała wiedzę we własnym zakresie zaś pozostałe $(22 \%)$ zadeklarowało, że w ogóle nie interesuje się tematyką związaną z samym nowotworem i profilaktyką.

Wnioski. Z przeprowadzonych badań wynika, że wiedza kobiet na temat profilaktyki raka szyjki macicy jest niezadawalająca. Brak wiedzy charakteryzował młodsze kobiety poniżej 20 roku życia. Zaledwie $42 \%$ badanych kobiet poddaje się profilaktycznym badaniom szyjki macicy. Akcje promujące zapobieganie nowotworowi są rzadko przeprowadzane oraz zbyt mało nagłaśniane $\mathrm{w}$ wyniku czego mały odsetek kobiet jest świadomy o przeprowadzanej akcji.

Słowa kluczowe: rak szyjki macicy, czynniki ryzyka, badania profilaktyczne

\section{Abstract:}

Introduction. Mortality in cervical cancer in Poland is one of the major oncological problems.

Aim. Evaluation of women's knowledge about the risk factors for cervical cancer and the possibility of preventing cancer through preventive examinations.

Material and methods. The study was carried out online. 135 women participated in the study. The research tool applied - the survey questionnaire containing 20 questions concerning the subject of the study. Information gathered in 135 survey questionnaires was analyzed. Based on the information obtained, statistical tables and graphs showing the distribution of the analyzed features were prepared. The women surveyed gave their consent and willingness to participate in the study and were informed of the anonymity of the study.

Results. In the study, $74 \%$ of women think that cytology is the best way to detectany abnormalities. The highest number of respondents who declared this were aged 21-30 and 41-50. As many as 39\% of women had never been examined for the early detection of cervical cancer and $12 \%$ do not 
remember when the study took place. Less than half $(42 \%)$ had a cytology caleradication performed in the last 3 years and approximately $7 \%$ of the women had it done within the last 3-5 years. Half of women know what frequency of cytology performance should be, unfortunately the other half are not awareofit. The doctor or the midwife $(26 \%)$ were referred to as a source of information concerning cervical cancer, half of the women surveyed(52\%) relied on their own knowledge, where as the remaining $22 \%$ declared that they were not interested in the issue related to the cancer it self and its prevention.

Conclusions. The studies show hatwomen's knowledge about cervical cancer prevention is unsatisfactory. Lack of knowledge was typical for younger women under 20 years of age. Only $42 \%$ of the women under go prophylactic cervical screening. Actions promoting cancer prevention are rarely performed and have insufficient publicity due to which a small percentage of women area ware of the action being performed.

Keywords: cervical cancer, risk factors, preventive examinations

\section{Wstęp}

Umieralność na raka szyjki macicy w Polsce wciąż stanowi jeden z głównych problemów onkologicznych, gdyż dziennie umiera 5 kobiet. Rocznie w Polsce na raka szyjki macicy dochodzi do zachorowań 4000 kobiet, natomiast 200 z nich umiera. Najwięcej chorujących pochodzi z przedziału wiekowego 45-59 lat. Główną przyczyną zmian jest zakażenie wirusem brodawczaka ludzkiego HPV o wysokim charakterze onkogennym np. HPV 16,18. Dodatkowymi czynnikami wywołującymi chorobę są: wczesne rozpoczęcie życia płciowego < 18 rokiem życia, posiadanie wielu partnerów seksualnych, szczególnie partnerów „wysokiego ryzyka”, stosowanie doustnej antykoncepcji hormonalnej, złe warunki socjoekonomiczne, niski poziom higieny osobistej, duża liczba porodów, palenie tytoniu [1].

Wczesne stadium raka szyjki macicy przebiega bezobjawowo. Dlatego szczególne znaczenie mają badania przesiewowe. 
W późniejszej fazie choroby pojawiają się krwawienia kontaktowe. Możemy wyróżnić następujące objawy: obrzęk kończyn, bolesne stosunki, trudności w oddawaniu moczu i stolca, obfite upławy, krwawienia międzymiesiączkowe, krwawienia po menopauzie, krwawienia pomiesiączkowe, ból w podbrzuszu oraz okolicy lędźwiowo - krzyżowej. Według przeprowadzonych badań naukowcy doszli do wniosku, że łój napletkowy, czyli wydzielina gruczołów napletka może wywierać działanie rakotwórcze w okolicy szyjki macicy oraz jej ujścia [2].

Badania przesiewowe polegają na pobraniu rozmazów cytologicznych z ujścia zewnętrznego szyjki macicy. Dzięki temu możemy rozpoznać zmiany przedrakowe oraz wcześnie wykryć nowotwór. Badania powinny być wykonywane w okresie co 3-5 lat w grupie wiekowej 30-60 lat. Niska cena pojedynczego badania w powiązaniu z jego skutecznością może ocalić nie jedno życie. Badanie cytologiczne odbywa się przy pomocy wziernika. Lekarz pobiera materiał komórkowy z szyjki macicy pacjentki [2]. Badania przesiewowe muszą spełniać pewne warunki: powinny być wykonywane w sposób ciągły, istnieje uzasadnienie konieczności ich wykonania, badanie przesiewowe dało wynik pozytywny, wykrycie choroby jest możliwe w fazie wczesnoobjawowej i przedklinicznej. Aby badanie było skuteczne musi być maksymalnie swoiste i czułe. W Polsce realizowane są Ogólnopolskie Programy Aktywnej Profilaktyki Raka Szyjki Macicy od 2004 roku. Realizowany jest on przez NFZ wobec wszystkich kobiet w wieku 25-59 lat. Pod uwage brany jest wiek oraz wcześniejsze leczenie onkologiczne $\mathrm{z}$ powodu raka szyjki macicy. Program składa się z trzyetapowej procedury obejmującej: I etap - rejestrację w SIMP, pobranie wymazu do badania cytologicznego, metody zapobiegania nowotworowi; II etap - ocenę wymazu; III etap - pogłębioną diagnostykę $\mathrm{w}$ przypadku nieprawidłowego wyniku cytologii [3].

Profilaktyka pierwotna jest pierwszym etapem w zapobieganiu rozwojowi choroby przez eliminowanie 
zewnętrznych czynników ryzyka. Profilaktyka wtórna jest drugim etapem i polega na wczesnym wykrywaniu raka szyjki macicy. Choroba jest wyleczalna w znacznym stopniu, kiedy nie daje znacznych objawów. Profilaktyka trzeciorzędowa nazywana późną ma miejsce w stadium klinicznym. Polega na zmniejszeniu skutków choroby oraz inwalidztwa, jakie może spowodować rak.

Szczepionka przeciwko wirusowi brodawczaka ludzkiego zapobiega zakażeniom wirusem HPV typu 6, 11, 16 i 18. Typ wirusa 16, 18 jest odpowiedzialny za raka szyjki macicy. Zgodnie z decyzją Komisji Europejskiej szczepionka jest wskazana dla dziewczynek w wieku od 9 do 15 lat oraz kobiet w wieku od 16 do 26 lat w celu zapobiegania powstaniu kłykcin kończystych spowodowanych wirusem HPV oraz zmianom przedrakowym szyjki macicy [4].

W leczeniu raka szyjki macicy stosuje się trzy metody: chemioterapię, radioterapię, chirurgię. Pierwsza metoda określana jest leczeniem systemowym, a pozostałe dwie - leczeniem miejscowym. W początkowym stadium choroby (0 i IA-1) stosowana jest konizacja, czyli chirurgiczne usunięcie stożka szyjki macicy. Od stopnia IA-2 do II-A stosowana jest histerektomia całkowita lub częściowa, która polega na usunięciu zmienionych chorobowo obszarów. Kolejnym przykładem leczenia jest histerektomia radykalna polegająca na całkowitym usunięciu macicy, górnej części pochwy oraz przyległych węzłów chłonnych. Rak szyjki macicy w stadium przedinwazyjnym daje pomyślne rokowanie, jest wyleczalny prawie całkowicie. Nowotwór w II stadium choroby daje $50 \%$ szans na wyleczenie. Śmiertelność wzrasta wraz ze stopniem raka szyjki macicy [4].

Celem pracy była próba oceny stanu wiedzy kobiet na temat raka szyjki macicy.

\section{Materiał i metody}

Badanie zostało przeprowadzone w okresie od listopada 2016 
roku do stycznia 2017 roku wśród 135 kobiet. Respondentki zostały podzielone na cztery grupy wiekowe. Najliczniejszą grupę stanowiły ankietowane w wieku do 20 lat - 35\% ogółu badanych. Drugą grupą pod względem liczebności były respondentki z przedziału 31 - 40 lat $26 \%$. Ankietowanych w wieku $41-50$ było niewiele mniej - $24 \%$. Najmniej liczną grupę stanowiły kobiety z przedziału 21 - 30 lat $15 \%$. Z analizy zebranych informacji wynika, iż prawie połowa $-47 \%$ - badanych kobiet posiada wykształcenie średnie - 64 osoby. Z kolei 39 osób posiada wykształcenie zawodowe, co odpowiada $29 \%$ ankietowanych. Wykształcenie wyższe dotyczy 20 badanych - 15\%, natomiast podstawowe 12 osób - 9\%. Zdecydowana większość respondentek podała jako miejsce swojego zamieszkania miasto - 83 kobiety - 61\%, 52 ankietowane mieszkało na wsi - 39\% (Tabela 1).

Tabela 1. Charakterystyka badanej grupy.

\begin{tabular}{|c|c|c|c|}
\hline Zmienne & Przedziały zmiennych & $\mathrm{N}$ & $\%$ \\
\hline \multirow[t]{4}{*}{ Wiek } & Poniżej 20 lat & 48 & 35 \\
\hline & $21-30$ lat & 20 & 15 \\
\hline & $31-40$ lat & 35 & 26 \\
\hline & $41-50$ lat & 32 & 24 \\
\hline \multirow[t]{4}{*}{ Wykształcenie } & Podstawowe & 12 & 9 \\
\hline & Zawodowe & 39 & 29 \\
\hline & Średnie & 64 & 47 \\
\hline & Wyższe & 20 & 15 \\
\hline \multirow[t]{2}{*}{ Miejsce zamieszkania } & Miasto & 83 & 61 \\
\hline & Wieś & 52 & 39 \\
\hline \multicolumn{2}{|c|}{ Razem } & 135 & 100 \\
\hline
\end{tabular}

Źródło: wyniki badań własnych

\section{Wyniki}

Wskazując najważniejsze badanie pozwalające wykryć 
wczesne zmiany na szyjce macicy, ankietowane miały do wyboru: badanie krwi, wymaz $\mathrm{z}$ pochwy, USG ginekologiczne, cytologia. Niecałe trzy czwarte kobiet (74\%) zna najważniejsze badanie pozwalające wykryć wczesne zmiany na szyjce macicy. Respondentki udzieliły następujących odpowiedzi:

- Badanie krwi: najmniej kobiet uważa, iż badanie krwi pozwala wykryć wczesne zmiany na szyjce macicy - 3\% badanych w wieku poniżej 20 roku życia.

- Wymaz z pochwy: 18\% kobiet, w tym najwięcej w wieku poniżej 20 roku życia - 38\%, następnie w wieku 31-40 - 17\%, a w wieku 21-30 i 41-50 - 0\%.

- USG ginekologiczne: wskazało 5\% kobiet, w tym najwięcej w wieku poniżej 20 roku życia - 8\%, następnie w wieku 31- 40 6\%, a w 21-30 i 41-50 - 0\%.

- Cytologia: jest uważana za najważniejsze badanie za pomocą, którego można wykryć raka szyjki macicy - wymieniło to badanie $74 \%$ kobiet, w tym najwięcej $\mathrm{w}$ wieku $21-30$ i $41-50$ po $100 \%$, następnie 31-40 - 74\%, zaś najmniej w wieku poniżej 20 roku życia - 46\% (Tabela 2).

Tabela 2. Badanie profilaktyczne pozwalające wykryć zmiany na szyjce macicy w opinii badanych.

\begin{tabular}{|c|c|c|c|c|c|c|c|c|c|c|}
\hline \multicolumn{1}{|c|}{ Pyt. Najważniejszym badaniem pozwalającym wykryć wczesne zmiany na szyjce } \\
macicy jest \\
\hline \multicolumn{3}{|c|}{ Razem } & $\begin{array}{c}\text { Poniżej } \\
20\end{array}$ & $21-30$ & $31-40$ & $41-50$ \\
\cline { 2 - 13 } & $\mathrm{N}$ & $\%$ & $\mathrm{~N}$ & $\%$ & $\mathrm{~N}$ & $\%$ & $\mathrm{~N}$ & $\%$ & $\mathrm{~N}$ & $\%$ \\
\hline Badanie krwi & 4 & 3 & 4 & 8 & 0 & 0 & 0 & 0 & 0 & 0 \\
\hline Wymaz z pochwy & 24 & 18 & 18 & 38 & 0 & 0 & 6 & 17 & 0 & 0 \\
\hline USG ginekologiczne & 7 & 5 & 4 & 8 & 0 & 0 & 2 & 6 & 0 & 0 \\
\hline Cytologia & 100 & 74 & 22 & 46 & 20 & 100 & 27 & 77 & 32 & 100 \\
\hline
\end{tabular}


Źródło: wyniki badań własnych

Jak wynika $\mathrm{z}$ analizy wyników 39\% kobiet nigdy nie badało się pod kątem wczesnego wykrywania raka szyjki macicy, a 12\% nie pamięta, kiedy takie badanie zostało wykonane. Blisko połowa respondentek (42\%) podała, że w ciągu ostatnich 3 lat miało pobierany wymaz cytologiczny, a około $7 \%$ kobiet - w ciągu ostatnich 3-5 lat (Tabela 3).

Tabela 3. Częstość wymazów cytologicznych wśród badanych.

\begin{tabular}{|c|c|c|c|c|c|c|c|c|c|c|}
\hline \multicolumn{8}{|c|}{ Pyt. Kiedy Pani ostatnio miała pobierany wymaz cytologiczny? } \\
\hline \multirow{2}{*}{} & Razem & \multicolumn{2}{|c|}{$\begin{array}{c}\text { Poniżej } \\
20\end{array}$} & $21-30$ & $31-40$ & $41-50$ \\
\cline { 2 - 13 } & $\mathrm{N}$ & $\%$ & $\mathrm{~N}$ & $\%$ & $\mathrm{~N}$ & $\%$ & $\mathrm{~N}$ & $\%$ & $\mathrm{~N}$ & $\%$ \\
\hline W ciągu ostatnich 3 lat & 56 & 42 & 10 & 21 & 8 & 40 & 20 & 57 & 18 & 56 \\
\hline 3-5 lat temu & 10 & 7 & 0 & 0 & 0 & 0 & 0 & 0 & 10 & 31 \\
\hline $\begin{array}{c}\text { Miałam, ale nie } \\
\text { pamiętam kiedy }\end{array}$ & 16 & 12 & 2 & 4 & 2 & 10 & 8 & 23 & 4 & 13 \\
\hline Nie miałam nigdy & 53 & 39 & 36 & 75 & 10 & 50 & 7 & 20 & 0 & 0 \\
\hline
\end{tabular}

Źródło: wyniki badań własnych

W przedziałach wiekowych:

- $\quad$ poniżej 20 lat: 71\% kobiet uważa, iż należy wykonywać cytologię co 3 lata, zaś 29\% z nich sądzi, iż częściej niż co 3 lata,

- 21-30 lat: 60\% kobiet uważa, iż należy wykonywać cytologię co 3 lata, zaś 29\% z nich uważa, że częściej niż co 3 lata,

- 31-40 lat: 37\% kobiet twierdzi, że należy wykonywać cytologię co 3 lata, zaś $37 \%$ z nich sądzi, iż częściej niż co 3 lata, a 26\% rzadziej niż co 3 lata,

- 41-50 lat: 25\% kobiet uważa, iż należy wykonywać cytologię co 3 lata, 56\% twierdzi, że częściej niż co 3 lata, 19\% - rzadziej niż co 3 lata (Tabela 4). 
Tabela 4. Częstość wykonywania cytologii wśród badanych.

\begin{tabular}{|c|c|c|c|c|c|c|c|c|c|c|}
\hline \multicolumn{10}{|c|}{ Pyt. Cytologię należy wykonywać } \\
\hline & Razem & \multicolumn{2}{|c|}{ Poniżej 20 } & \multicolumn{2}{|c|}{$21-30$} & \multicolumn{2}{|c|}{$31-40$} & \multicolumn{2}{|c|}{$41-50$} \\
\hline & $\mathrm{N}$ & $\%$ & $\mathrm{~N}$ & $\%$ & $\mathrm{~N}$ & $\%$ & $\mathrm{~N}$ & $\%$ & $\mathrm{~N}$ & $\%$ \\
\hline Co 3 lata & 67 & 50 & 34 & 71 & 12 & 60 & 13 & 37 & 8 & 25 \\
\hline Częściej niż co 3 lata & 53 & 39 & 14 & 29 & 8 & 40 & 13 & 37 & 18 & 56 \\
\hline Rzadziej niż co 3 lata & 15 & 11 & 0 & 0 & 0 & 0 & 9 & 26 & 6 & 19 \\
\hline
\end{tabular}

Źródło: wyniki badań własnych

Prawie wszystkie kobiety tj. 96\% twierdzą, że wiedzą, jak przebiega badanie cytologiczne.

W przedziałach wiekowych:

- poniżej 20 lat: 88\% respondentek sądzi, iż przy pomocy wziernika lekarz pobiera materiał komórkowy z szyjki macicy pacjentki, zaś $8 \%$ - rozpoznanie stwierdzane jest na podstawie składu moczu kobiety, a $4 \%$ badanych uważa, iż wykonuje się rentgen macicy z użyciem kontrastu,

- 21-30 lat: 100\% badanych sądzi, iż przy pomocy wziernika lekarz pobiera materiał komórkowy z szyjki macicy pacjentki,

- 31-40 lat: 88\% respondentek sądzi, iż przy pomocy wziernika lekarz pobiera materiał komórkowy z szyjki macicy pacjentki,

- 41-50 lat: 88\% badanych uważa, że przy pomocy wziernika lekarz pobiera materiał komórkowy z szyjki macicy pacjentki (Tabela 5).

Tabela 5. Przebieg badania cytologicznego w opinii badanych.

\begin{tabular}{|c|c|c|c|c|c|c|c|c|c|c|}
\hline \multicolumn{11}{|c|}{ Pyt. Jak wygląda badanie cytologiczne? } \\
\hline & \multicolumn{2}{|c|}{ Razem } & \multicolumn{2}{|c|}{$\begin{array}{c}\text { Poniżej } \\
20\end{array}$} & \multicolumn{2}{|c|}{$21-30$} & \multicolumn{2}{|c|}{$31-40$} & \multicolumn{2}{|c|}{$41-50$} \\
\hline & $\mathrm{N}$ & $\%$ & $\mathrm{~N}$ & $\%$ & $\mathrm{~N}$ & $\%$ & $\mathrm{~N}$ & $\%$ & $\mathrm{~N}$ & $\%$ \\
\hline przy pomocy wziernika & 129 & 96 & 42 & 88 & 20 & 100 & 35 & 100 & 32 & 100 \\
\hline
\end{tabular}




\begin{tabular}{|c|c|c|c|c|c|c|c|c|c|c|}
\hline $\begin{array}{c}\text { lekarz pobiera materiał } \\
\text { komórkowy z szyjki } \\
\text { macicy pacjentki }\end{array}$ & & & & & & & & & & \\
\hline $\begin{array}{c}\text { rozpoznanie } \\
\text { stwierdzamy na } \\
\text { podstawie składu } \\
\text { moczu kobiety }\end{array}$ & 4 & 3 & 4 & 8 & 0 & 0 & 0 & 0 & 0 & 0 \\
\hline $\begin{array}{c}\text { wykonuje się rentgen } \\
\text { macicy z użyciem } \\
\text { kontrastu }\end{array}$ & 2 & 1 & 2 & 4 & 0 & 0 & 0 & 0 & 0 & 0 \\
\hline
\end{tabular}

Źródło: wyniki badań własnych

Badanie cytologiczne z własnej inicjatywy wykonuje 39\% respondentek. Około jedna czwarta zgłasza się na badanie na polecenie lekarza (23\%) i położnej (3\%). Niestety aż 35\% kobiet nie poddaje się badaniu.

W przedziałach wiekowych:

- poniżej 20 lat: 8\% kobiet uważa, iż inicjatorem badań cytologicznych jest lekarz, 4\% -położna, 21\% respondentek jest inicjatorkami badania, $21 \%$ kobiet wcale się nie bada,

- 21-30lat: 40\% kobiet uważa, iż inicjatorem badań cytologicznych są same kobiety, $60 \%$ ankietowanych wcale się nie poddaje się badaniu,

- 31-40 lat: 49\% kobiet uważa, iż inicjatorem badań cytologicznych jest lekarz, 40\% ankietowanych twierdzi, że same kobiety są inicjatorkami badania, $11 \%$ kobiet wcale się nie uczestniczy w badaniach,

- 41-50 lat: 31\% kobiet uważa, iż inicjatorem badań cytologicznych jest lekarz, $7 \%$ - położna, $62 \%$ ankietowanych twierdzi, że same kobiety są inicjatorkami badania (Tabela 6).

Tabela 6. Inicjator badań cytologicznych w opinii badanych. 


\begin{tabular}{|c|c|c|c|c|c|c|c|c|c|c|}
\hline \multicolumn{10}{|c|}{ Pyt. Z czyjej inicjatywy wykonuje Pani badanie cytologiczne? } \\
\hline & Razem & \multicolumn{2}{|c|}{ Poniżej 20} & \multicolumn{2}{|c|}{$21-30$} & \multicolumn{2}{|c|}{$31-40$} & \multicolumn{2}{|c|}{$41-50$} \\
\hline & $\mathrm{N}$ & $\%$ & $\mathrm{~N}$ & $\%$ & $\mathrm{~N}$ & $\%$ & $\mathrm{~N}$ & $\%$ & $\mathrm{~N}$ & $\%$ \\
\hline Lekarza & 31 & 23 & 4 & 8 & 0 & 0 & 17 & 49 & 10 & 31 \\
\hline Położnej & 4 & 3 & 2 & 4 & 0 & 0 & 0 & 0 & 2 & 7 \\
\hline Własnej & 52 & 39 & 10 & 21 & 8 & 40 & 14 & 40 & 20 & 62 \\
\hline Nie badam się & 48 & 35 & 32 & 67 & 12 & 60 & 4 & 11 & 0 & 0 \\
\hline
\end{tabular}

Źródło: wyniki badań własnych

Niecałe trzy czwarte kobiet (74\%) wie, że wykonując regularne badania można uniknąć nowotworu szyjki macicy.

W przedziałach wiekowych:

- poniżej 20 lat: 71\% kobiet uważa, iż wykonując regularne badania można uniknąć raka szyjki macicy, a 29\% nie posiada takiej wiedzy,

- 21-30 lat: 80\% kobiet uważa, iż wykonując regularne badania można uniknąć raka szyjki macicy, a $20 \%$ z nich nie potwierdza tego stwierdzenia,

- 31-40 lat: 80\% kobiet uważa, iż wykonując regularne badania można uniknąć raka szyjki macicy, a $20 \%$ z nich nie podziela tego zdania,

- 41-50 lat: 69\% kobiet uważa, iż wykonując regularne badania można uniknąć raka szyjki macicy, a 31\% z nich uważa, że tak nie jest (Tabela 7).

Tabela 7. Profilaktyka raka szyjki macicy w opinii badanych.

\begin{tabular}{|c|c|c|c|c|c|c|c|c|c|c|}
\hline \multicolumn{2}{|c|}{ Pyt. Czy wykonując regularne badania można uniknąć raka szyjki macicy? } \\
\hline & \multicolumn{2}{|c|}{ Razem } & \multicolumn{2}{|c|}{ Poniżej 20} & $21-30$ & \multicolumn{2}{|c|}{$31-40$} & \multicolumn{2}{|c|}{$41-50$} \\
\cline { 2 - 11 } & $\mathrm{N}$ & $\%$ & $\mathrm{~N}$ & $\%$ & $\mathrm{~N}$ & $\%$ & $\mathrm{~N}$ & $\%$ & $\mathrm{~N}$ & $\%$ \\
\hline Tak & 100 & 74 & 34 & 71 & 16 & 80 & 28 & 80 & 22 & 69 \\
\hline Nie & 21 & 16 & 0 & 0 & 4 & 20 & 7 & 20 & 10 & 31 \\
\hline
\end{tabular}




\begin{tabular}{|c|c|c|c|c|c|c|c|c|c|c|}
\hline Nie wiem & 14 & 10 & 14 & 29 & 0 & 0 & 0 & 0 & 0 & 0 \\
\hline
\end{tabular}

Źródło: wyniki badań własnych

Większość kobiet ( 89\%) twierdzi, że wie jakiej grupy kobiet częściej dotyczy nowotwór.

W przedziałach wiekowych:

- poniżej 20 lat: 79\% ankietowanych uważa, iż rak szyjki macicy częściej występuje u kobiet mających wielu partnerów, a 21\% podaje, że dotyczy to mężatek,

- 21 - 30 lat: 100\% badanych uważa, iż rak szyjki macicy częściej występuje u kobiet posiadających wielu partnerów,

- 31-40 lat: 100\% respondentek uważa, iż rak szyjki macicy częściej występuje u kobiet mających wielu partnerów,

- 41-50 lat: 82\% badanych sądzi, że rak szyjki macicy częściej występuje u kobiet mających wielu partnerów, a 12\% badanych podaje, że dotyczy to mężatek, a 6\% sądzi, że taka sytuacja dotyczy kobiet, które nie podjęły aktywności seksualnej (Tabela 8).

Tabela 8. Opinia badanych dotycząca grupy kobiet $\mathrm{z}$ ryzykiem wystąpienia raka szyjki macicy.

\begin{tabular}{|c|c|c|c|c|c|c|c|c|c|c|}
\hline \multicolumn{11}{|c|}{ Pyt. Rak szyjki macicy częściej występuje u: } \\
\hline & \multicolumn{2}{|c|}{ Razem } & \multicolumn{2}{|c|}{$\begin{array}{c}\text { Poniżej } \\
20\end{array}$} & \multicolumn{2}{|c|}{$21-30$} & \multicolumn{2}{|c|}{$31-40$} & \multicolumn{2}{|c|}{$41-50$} \\
\hline & $\mathrm{N}$ & $\%$ & $\mathrm{~N}$ & $\%$ & $\mathrm{~N}$ & $\%$ & $\mathrm{~N}$ & $\%$ & $\mathrm{~N}$ & $\%$ \\
\hline $\begin{array}{l}\text { Kobiet mających } \\
\text { wielu partnerów }\end{array}$ & 119 & 89 & 38 & 79 & 20 & 100 & 35 & 100 & 26 & 82 \\
\hline Mężatek & 14 & 10 & 10 & 21 & 0 & 0 & 0 & 0 & 4 & 12 \\
\hline $\begin{array}{c}\text { Kobiet, które nie } \\
\text { podjęły aktywności } \\
\text { seksualnej }\end{array}$ & 2 & 1 & 0 & 0 & 0 & 0 & 0 & 0 & 2 & 6 \\
\hline
\end{tabular}

Źródło: wyniki badań własnych 
Ponad połowa kobiet (54\%)twierdzi, że zna główną przyczynę raka szyjki macicy.

W przedziałach wiekowych:

- $\quad$ poniżej 20 lat: 58\% kobiet sądzi, że główną przyczyną raka szyjki macicy są czynniki genetyczne, zaś $42 \%$ - wskazuje na wirusa HPV,

- 21-30 lat: 10\% kobiet sądzi, że główną przyczyną raka szyjki macicy są czynniki genetyczne, zaś $90 \%$ ankietowanych podaje wirusa HPV,

- 31-40 lat: 34\% kobiet sądzi, że główną przyczyną raka szyjki macicy są czynniki genetyczne, zaś $66 \%$ podaje wirusa HPV,

- 41-50 lat: 63\% kobiet twierdzi, że główną przyczyną raka szyjki macicy są czynniki genetyczne, zaś $37 \%$ podaje wirusa HPV (Tabela 9).

Tabela 9. Przyczyna raka szyjki macicy w opinii badanych.

\begin{tabular}{|c|c|c|c|c|c|c|c|c|c|c|}
\hline \multicolumn{10}{|c|}{ Pyt. Główną przyczyną raka szyjki macicy jest: } \\
\hline & \multicolumn{2}{|c|}{ Razem } & \multicolumn{2}{|c|}{ Poniżej 20} & \multicolumn{2}{|c|}{$21-30$} & \multicolumn{2}{|c|}{$31-40$} & \multicolumn{2}{|c|}{$41-50$} \\
\cline { 2 - 12 } & $\mathrm{N}$ & $\%$ & $\mathrm{~N}$ & $\%$ & $\mathrm{~N}$ & $\%$ & $\mathrm{~N}$ & $\%$ & $\mathrm{~N}$ & $\%$ \\
\hline Alkohol & 0 & 0 & 0 & 0 & 0 & 0 & 0 & 0 & 0 & 0 \\
\hline Czynniki genetyczne & 62 & 46 & 28 & 58 & 2 & 10 & 12 & 34 & 20 & 63 \\
\hline Wirus HPV & 73 & 54 & 20 & 42 & 18 & 90 & 23 & 66 & 12 & 37 \\
\hline
\end{tabular}

Źródło: wyniki badań własnych

Ponad trzy czwarte kobiet (76\%) twierdzi, że umie wskazać prawidłowy objaw raka szyjki macicy.

W przedziałach wiekowych:

- poniżej 20 lat: 54\% kobiet uważa, iż typowym objawem raka szyjki macicy jest krwawienie z pochwy, 38\% - częstomocz zaś $8 \%$ badanych -bóle kończyn dolnych,

- 21-30 lat: 60\% kobiet uważa, iż typowym objawem raka szyjki 
macicy jest krwawienie $\mathrm{z}$ pochwy, 10\% - częstomocz, 30\% respondentek - bóle kończyn dolnych,

- 31-40 lat: 94\% kobiet uważa, iż typowym objawem raka szyjki macicy jest krwawienie z pochwy, 6\% badanych podaje, że bóle kończyn dolnych,

- 41-50 lat: 100\% kobiet uważa, iż typowym objawem raka szyjki macicy jest krwawienie z pochwy (Tabela 10).

Tabela 10. Objawy raka szyjki macicy w opinii badanych.

\begin{tabular}{|c|c|c|c|c|c|c|c|c|c|c|}
\hline \multicolumn{8}{|c|}{ Pyt. Typowy objaw raka szyjki macicy: } \\
\hline \multicolumn{2}{|c|}{ Razem } & \multicolumn{2}{c|}{\begin{tabular}{c} 
Poniżej \\
\multicolumn{2}{|c|}{20}
\end{tabular}} & \multicolumn{2}{c|}{$21-30$} & \multicolumn{2}{|c|}{$31-40$} & \multicolumn{2}{c|}{$41-50$} \\
\cline { 2 - 12 } & $\mathrm{N}$ & $\%$ & $\mathrm{~N}$ & $\%$ & $\mathrm{~N}$ & $\%$ & $\mathrm{~N}$ & $\%$ & $\mathrm{~N}$ & $\%$ \\
\hline $\begin{array}{c}\text { Krwawienie z } \\
\text { pochwy }\end{array}$ & 103 & 76 & 26 & 54 & 12 & 60 & 33 & 94 & 32 & 100 \\
\hline $\begin{array}{c}\text { Bóle kończyn } \\
\text { dolnych }\end{array}$ & 12 & 9 & 4 & 8 & 6 & 30 & 2 & 6 & 0 & 0 \\
\hline Częstomocz & 20 & 15 & 18 & 38 & 2 & 10 & 0 & 0 & 0 & 0 \\
\hline
\end{tabular}

Źródło: wyniki badań własnych

Prawie wszystkie kobiety wiedzą (99\%) twierdzą, że wiedzą, w jaki sposób można zarazić się wirusem brodawczaka ludzkiego.

W przedziałach wiekowych:

- poniżej 20 lat: 96\% kobiet uważa, iż wirusem brodawczaka ludzkiego można zarazić się poprzez współżycie seksualne, zaś $4 \%$ podaje, że poprzez picie z jednego kubka,

- 21-30 lat: 100\% kobiet uważa, iż wirusem brodawczaka ludzkiego można zarazić się poprzez współżycie seksualne,

- 31-40 lat: $100 \%$ kobiet uważa, iż wirusem brodawczaka ludzkiego można zarazić się poprzez współżycie seksualne,

- 41-50 lat: 100\% kobiet uważa, iż wirusem brodawczaka 
ludzkiego można zarazić się poprzez współżycie seksualne (Tabela 11).

Tabela 11. Zakażenie wirusem brodawczaka ludzkiego $w$ opinii badanych.

\begin{tabular}{|c|c|c|c|c|c|c|c|c|c|c|}
\hline \multicolumn{11}{|c|}{ Pyt. Wirusem brodawczaka ludzkiego można zarazić się przez: } \\
\hline & \multicolumn{2}{|c|}{ Razem } & \multicolumn{2}{|c|}{$\begin{array}{c}\text { Poniżej } \\
20\end{array}$} & \multicolumn{2}{|c|}{$21-30$} & \multicolumn{2}{|c|}{$31-40$} & \multicolumn{2}{|c|}{$41-50$} \\
\hline & $\mathrm{N}$ & $\%$ & $\mathrm{~N}$ & $\%$ & $\mathrm{~N}$ & $\%$ & $\mathrm{~N}$ & $\%$ & $\mathrm{~N}$ & $\%$ \\
\hline $\begin{array}{l}\text { Rozmowę z } \\
\text { zakażonym }\end{array}$ & 0 & 0 & 0 & 0 & 0 & 0 & 0 & 0 & 0 & 0 \\
\hline $\begin{array}{l}\text { Współżycie } \\
\text { seksualne }\end{array}$ & 133 & 99 & 46 & 96 & 20 & 100 & 35 & 100 & 32 & 100 \\
\hline $\begin{array}{c}\text { Picie z jednego } \\
\text { kubka }\end{array}$ & 2 & 1 & 2 & 4 & 0 & 0 & 0 & 0 & 0 & 0 \\
\hline
\end{tabular}

Źródło: wyniki badań własnych

Blisko trzy czwarte kobiet (73\%) uważa, że zna najlepszą metodę uniknięcia kontaktu $\mathrm{z}$ wirusem wywołującym nowotwór szyjki macicy.

W przedziałach wiekowych:

- poniżej 20 lat: 82\% kobiet uważa, iż najlepszą metodą uniknięcia kontaktu z wirusem jest jak najpóźniejsze rozpoczęcie współżycia płciowego, $9 \%$ podaje, że jest to wieloletnie stosowanie antykoncepcji hormonalnej, 9\% - współżycie z mężczyzną nieobrzezanym,

- 21-30 lat: 80\% kobiet uważa, iż najlepszą metodą uniknięcia kontaktu z wirusem jest jak najpóźniejsze rozpoczęcie współżycia płciowego, $20 \%$ podaje, że jest to wieloletnie stosowanie antykoncepcji hormonalnej,

- 31-40 lat: 63\% kobiet uważa, iż najlepszą metodą uniknięcia 
kontaktu z wirusem jest jak najpóźniejsze rozpoczęcie współżycia płciowego, $37 \%$ podaje, że jest to wieloletnie stosowanie antykoncepcji hormonalnej,

- 41-50 lat: 63\% kobiet uważa, iż najlepszą metodą uniknięcia kontaktu z wirusem jest jak najpóźniejsze rozpoczęcie współżycia płciowego, $37 \%$ twierdzi, że jest to wieloletnie stosowanie antykoncepcji hormonalnej (Tabela 12).

Tabela12. Metoda uniknięcia kontaktu $\mathrm{z}$ wirusem brodawczaka ludzkiego w opinii badanych.

\begin{tabular}{|c|c|c|c|c|c|c|c|c|c|c|}
\hline \multicolumn{11}{|c|}{ Pyt. Najlepszą metodą uniknięcia kontaktu z wirusem jest: } \\
\hline & \multicolumn{2}{|c|}{ Razem } & \multicolumn{2}{|c|}{$\begin{array}{c}\text { Poniżej } \\
20\end{array}$} & \multicolumn{2}{|c|}{$21-30$} & \multicolumn{2}{|c|}{$31-40$} & \multicolumn{2}{|c|}{$41-50$} \\
\hline & $\mathrm{N}$ & $\%$ & $\mathrm{~N}$ & $\%$ & $\mathrm{~N}$ & $\%$ & $\mathrm{~N}$ & $\%$ & $\mathrm{~N}$ & $\%$ \\
\hline $\begin{array}{c}\text { Jak najpóźniejsze } \\
\text { rozpoczęcie współżycia } \\
\text { płciowego }\end{array}$ & 98 & 73 & 40 & 82 & 16 & 80 & 22 & 63 & 20 & 63 \\
\hline $\begin{array}{c}\text { Wieloletnie stosowanie } \\
\text { antykoncepcji } \\
\text { hormonalnej }\end{array}$ & 33 & 24 & 4 & 9 & 4 & 20 & 13 & 37 & 12 & 37 \\
\hline $\begin{array}{c}\text { Współżycie z } \\
\text { mężczyzną } \\
\text { nieobrzezanym }\end{array}$ & 4 & 3 & 4 & 9 & 0 & 0 & 0 & 0 & 0 & 0 \\
\hline
\end{tabular}

Źródło: wyniki badań własnych

Większość kobiet tj. 88\% twierdzi, że potrafi wskazać jedną z metod leczenia wczesnych postaci nowotworu.

W przedziałach wiekowych:

- poniżej 20 lat: 79\% kobiet uważa, że jedną z metod leczenia wczesnych postaci raka szyjki macicy jest histerektomia, 4\%,rentgen, a 17\%, że jest to kolonoskopia, 
- 21 - 30 lat: 100\% kobiet uważa, że jedną z metod leczenia wczesnych postaci raka szyjki macicy jest histerektomia,

- 31 - 40 lat: 94\% kobiet twierdzi, że jedną z metod leczenia wczesnych postaci raka szyjki macicy jest histerektomia, a 6\% że jest to kolonoskopia,

- 41 - 50 lat: 88\% kobiet uważa, że jedną z metod leczenia wczesnych postaci raka szyjki macicy jest histerektomia, 8\% rentgen, a 6\% - kolonoskopia (Tabela 13).

Tabela 13. Metoda leczenia wczesnej postaci raka szyjki macicy w opinii badanych.

\begin{tabular}{|c|c|c|c|c|c|c|c|c|c|c|}
\hline \multicolumn{2}{|c|}{ Pyt. Jedną z metod leczenia wczesnych postaci raka szyjki macicy jest: } \\
\hline & Razem & \multicolumn{2}{|c|}{ Poniżej 20} & \multicolumn{2}{|c|}{$21-30$} & \multicolumn{2}{|c|}{$31-40$} & \multicolumn{2}{|c|}{$41-50$} \\
\cline { 2 - 13 } & $\mathrm{N}$ & $\%$ & $\mathrm{~N}$ & $\%$ & $\mathrm{~N}$ & $\%$ & $\mathrm{~N}$ & $\%$ & $\mathrm{~N}$ & $\%$ \\
\hline Rentgen & 4 & 3 & 2 & 4 & 0 & 0 & 0 & 0 & 2 & 6 \\
\hline Histerektomia & 119 & 88 & 38 & 79 & 20 & 100 & 33 & 94 & 28 & 88 \\
\hline Kolonoskopia & 12 & 9 & 8 & 17 & 0 & 0 & 2 & 6 & 2 & 6 \\
\hline
\end{tabular}

Źródło: wyniki badań własnych

Prawie wszystkie kobiety (97\%) twierdzą, że wiedzą w jakim wieku najczęściej rozwija się rak szyjki macicy.

W przedziałach wiekowych:

- poniżej 20 lat: 92\% kobiet uważa, iż rak szyjki macicy najczęściej rozwija się u kobiet pomiędzy 30 a 59 rokiem życia, natomiast 8\%, że w wieku 10-20 lat,

- $\quad 21$ - 30 lat: 100\% kobiet uważa, iż rak szyjki macicy najczęściej rozwija się u kobiet pomiędzy 30 a 59 rokiem życia,

- 31 - 40 lat:100\% kobiet uważa, iż rak szyjki macicy najczęściej rozwija się u kobiet pomiędzy 30 a 59 rokiem życia,

- 41 - 50 lat: 100\% kobiet uważa, iż rak szyjki macicy najczęściej rozwija się u kobiet pomiędzy 30 a 59 rokiem życia (Tabela 14). 
Tabela 14. Przedział wieku, w którym rozwija się rak szyjki macicy w opinii badanych.

\begin{tabular}{|c|c|c|c|c|c|c|c|c|c|c|}
\hline \multicolumn{1}{|c|}{ Pyt. Najczęściej rak szyjki macicy rozwija się u kobiet pomiędzy: } \\
\hline \multicolumn{1}{|c|}{ Razem } & \multicolumn{2}{|c|}{ Poniżej 20 } & \multicolumn{2}{|c|}{$21-30$} & \multicolumn{2}{|c|}{$31-40$} & \multicolumn{2}{|c|}{$41-50$} \\
\cline { 2 - 11 } & $\mathrm{N}$ & $\%$ & $\mathrm{~N}$ & $\%$ & $\mathrm{~N}$ & $\%$ & $\mathrm{~N}$ & $\%$ & $\mathrm{~N}$ & $\%$ \\
\hline $10-20$ & 4 & 3 & 4 & 8 & 0 & 0 & 0 & 0 & 0 & 0 \\
\hline $30-59$ & 131 & 97 & 44 & 92 & 20 & 100 & 35 & 100 & 32 & 100 \\
\hline $70-85$ & 0 & 0 & 0 & 0 & 0 & 0 & 0 & 0 & 0 & 0 \\
\hline
\end{tabular}

Źródło: wyniki badań własnych

Zdecydowana większość kobiet (85\%) uważa, że zna skuteczną metody ochrony przed zachorowaniem na nowotwór szyjki macicy. W przedziałach wiekowych:

- $\quad$ poniżej 20 lat: $67 \%$ kobiet uważa, że skuteczna ochrona przed zachorowaniem na raka szyjki macicy to szczepienie, 29\% wskazuje na korzystanie $\mathrm{z}$ witamin, natomiast $4 \%$, że jest to odpowiednia dieta,

- $\quad 21$ - 30 lat: 100\% kobiet uważa, że skuteczna ochrona przed zachorowaniem na raka szyjki macicy to szczepienie,

- $\quad 31$ - 40 lat: 94\% kobiet uważa, że skuteczna ochrona przed zachorowaniem na raka szyjki macicy to szczepienie, a $6 \%$ podaje, że jest to odpowiednia dieta,

- 41 - 50 lat: 94\% kobiet uważa, że skuteczna ochrona przed zachorowaniem na raka szyjki macicy to szczepienie, a $6 \%$ podaje, że jest to odpowiednia dieta (Tabela 15).

Tabela 15. Ochrona przed rakiem szyjki macicy $w$ opinii badanych.

\begin{tabular}{|l|l|l|l|l|l|}
\hline \multicolumn{1}{|c|}{ Pyt. Skuteczna ochrona przed zachorowaniem na raka szyjki macicy to lat: } \\
\hline & Razem & Poniżej 20 & $21-30$ & $31-40$ & $41-50$ \\
\hline
\end{tabular}




\begin{tabular}{|c|c|c|c|c|c|c|c|c|c|c|}
\hline & $\mathrm{N}$ & $\%$ & $\mathrm{~N}$ & $\%$ & $\mathrm{~N}$ & $\%$ & $\mathrm{~N}$ & $\%$ & $\mathrm{~N}$ & $\%$ \\
\hline Witaminy & 2 & 1 & 2 & 29 & 0 & 0 & 0 & 0 & 0 & 0 \\
\hline $\begin{array}{c}\text { Odpowiednia } \\
\text { dieta }\end{array}$ & 18 & 14 & 14 & 4 & 0 & 0 & 2 & 6 & 2 & 6 \\
\hline Szczepienie & 115 & 85 & 32 & 67 & 20 & 100 & 33 & 94 & 30 & 94 \\
\hline
\end{tabular}

Źródło: wyniki badań własnych

Większość kobiet (87\%) podaje, że wie, które kobiety mogą korzystać ze szczepionki przeciwko wirusowi brodawczaka ludzkiego.

W przedziałach wiekowych:

- poniżej 20 lat: 83\% kobiet uważa, że zaszczepić mogą się dziewczęta od 11-12 roku życia jeszcze przed inicjacją seksualną i kobiety aktywne seksualnie, natomiast $17 \%$ ankietowanych podaje, że dotyczy to tylko kobiet po 50 roku życia,

- 21 - 30 lat: 100\% kobiet uważa, że zaszczepić mogą się dziewczęta od 11-12 roku życia jeszcze przed inicjacją seksualną i kobiety aktywne seksualnie,

- $\quad 31$ - 40 lat:77\% kobiet uważa, że zaszczepić mogą się dziewczęta od 11-12 roku życia jeszcze przed inicjacją seksualną i kobiety aktywne seksualnie, natomiast $23 \%$ badanych podaje, że mogą uczynić to tylko kobiety po 50 roku życia,

- $\quad 41$ - 50 lat:94\% kobiet uważa, że zaszczepić mogą się dziewczęta od 11-12 roku życia jeszcze przed inicjacją seksualną i kobiety aktywne seksualnie, natomiast $6 \%$ respondentek podaje, że mogą poddać się szczepieniu tylko kobiety po 50 roku życia (Tabela16).

Tabela 16. Korzystanie ze szczepień przeciwko wirusowi brodawczaka ludzkiego $\mathrm{w}$ opinii badanych.

\begin{tabular}{|l|c|c|c|c|c|}
\hline \multicolumn{7}{|c|}{ Pyt. Kto może się zaszczepić? } \\
\hline & Razem & Poniżej & $21-30$ & $31-40$ & $41-50$ \\
\hline
\end{tabular}




\begin{tabular}{|c|c|c|c|c|c|c|c|c|c|c|}
\hline & \multicolumn{2}{|c|}{} & \multicolumn{2}{|c|}{20} & \multicolumn{2}{|c|}{} & \multicolumn{2}{|c|}{} & \multicolumn{2}{|c|}{} \\
\cline { 2 - 12 } & $\mathrm{N}$ & $\%$ & $\mathrm{~N}$ & $\%$ & $\mathrm{~N}$ & $\%$ & $\mathrm{~N}$ & $\%$ & $\mathrm{~N}$ & $\%$ \\
\hline $\begin{array}{c}\text { Tylko kobiety po 50 } \\
\text { roku życia }\end{array}$ & 18 & 13 & 8 & 17 & 0 & 0 & 8 & 23 & 2 & 6 \\
\hline $\begin{array}{c}\text { Kobiety w ciąży } \\
\text { Dziewczęta od 11-12 } \\
\text { roku życia jeszcze } \\
\text { przed inicjacją } \\
\text { seksualną, kobiety } \\
\text { aktywne seksualnie }\end{array}$ & 117 & 87 & 40 & 83 & 20 & 100 & 27 & 77 & 30 & 94 \\
\hline
\end{tabular}

Źródło: wyniki badań własnych

Blisko jedna czwarta badanych kobiet tj. 36\% wie, do kogo jest kierowany Populacyjny Program Profilaktyki i Wczesnego Wykrywania Raka Szyjki Macicy.

W przedziałach wiekowych:

- poniżej 20 lat: 34\% kobiet uważa, że program jest adresowany do kobiet między 25 a 59 rokiem życia, 58\% twierdzi, że obejmuje wszystkie kobiety, zaś $8 \%$ badanych uważa, że jest kierowany do nastolatek,

- 21 - 30 lat: 50\% kobiet uważa, że Populacyjny Program Profilaktyki i Wczesnego Wykrywania Raka Szyjki Macicy adresowany jest do kobiet między 25 a 59 rokiem życia, 50\% badanych uważa, że obejmuje on wszystkie kobiety,

- 31 - 40 lat: 51\% kobiet uważa, że program adresowany jest do kobiet między 25 a 59 rokiem życia, $49 \%$ badanych podaje, że obejmuje on wszystkie kobiety,

- 41 - 50 lat: 12\% kobiet uważa, że Populacyjny Program Profilaktyki i Wczesnego Wykrywania Raka Szyjki Macicy adresowany jest do kobiet między 25 a 59 rokiem życia, 88\% ankietowanych twierdzi, że obejmuje wszystkie kobiety, zaś $8 \%$ - 
że jest on kierowany do nastolatek (Tabela 17).

Tabela 17. Adresatki Populacyjnego Programu Profilaktyki i Wczesnego Wykrywania Raka Szyjki Macicy w opinii badanych.

\begin{tabular}{|c|c|c|c|c|c|c|c|c|c|c|}
\hline \multicolumn{11}{|c|}{$\begin{array}{l}\text { Pyt. Do kogo adresowany jest Populacyjny Program Profi } \\
\text { Wykrywania Raka Szyjki Macicy? }\end{array}$} \\
\hline & \multicolumn{2}{|c|}{ Razem } & \multicolumn{2}{|c|}{$\begin{array}{l}\text { Poniżej } \\
20\end{array}$} & \multicolumn{2}{|c|}{$21-30$} & \multicolumn{2}{|c|}{$31-40$} & \multicolumn{2}{|c|}{$41-50$} \\
\hline & $\mathrm{N}$ & $\%$ & $\mathrm{~N}$ & $\%$ & $\mathrm{~N}$ & $\%$ & $\mathrm{~N}$ & $\%$ & $\mathrm{~N}$ & $\%$ \\
\hline Do nastolatek & 4 & 3 & 4 & 8 & 0 & 0 & 0 & 0 & 0 & 0 \\
\hline $\begin{array}{l}\text { Kobiety między } 25 \text { a } 59 \\
\text { rokiem życia }\end{array}$ & 48 & 36 & 16 & 34 & 10 & 50 & 18 & 51 & 4 & 12 \\
\hline $\begin{array}{c}\text { Obejmuje wszystkie } \\
\text { kobiety }\end{array}$ & 83 & 61 & 28 & 58 & 10 & 50 & 17 & 49 & 28 & 88 \\
\hline
\end{tabular}

Źródło: wyniki badań własnych

Ponad połowa badanych (52\%) poszukuje wiedzy na temat raka szyjki macicy we własnym zakresie, około jedna czwarta kobiet zdobywa informacje u lekarza lub położnej (26\%), zaś aż $22 \%$ respondentek w ogóle nie interesuje się tematyką związaną z samym nowotworem i profilaktyką.

W przedziałach wiekowych:

- poniżej 20 lat: 58\% kobiet poszukuje wiedzy na temat raka szyjki macicy i profilaktyki we własnym zakresie, $0 \%$ od lekarza ginekologa, $1 \%$ od położnej, natomiast aż $41 \%$ kobiet nie interesuje się tym zagadnieniem,

- $\quad 21$ - 30 lat: $80 \%$ kobiet poszukuje informacji na temat raka szyjki macicy i profilaktyki we własnym zakresie, $0 \%$ od lekarza ginekologa, $0 \%$ od położnej, natomiast aż $20 \%$ kobiet nie interesuje się tym tematem,

- 31 - 40 lat: $46 \%$ kobiet poszukuje wiedzy na temat raka szyjki 
macicy i profilaktyki we własnym zakresie, 49\% od lekarza ginekologa, $0 \%$ od położnej, natomiast $5 \%$ kobiet nie interesuje się tym zagadnieniem,

- $\quad 41$ - 50 lat: $44 \%$ kobiet poszukuje informacji na temat raka szyjki macicy i profilaktyki we własnym zakresie, 44\% od lekarza ginekologa, $0 \%$ od położnej, natomiast $12 \%$ kobiet nie interesuje się tym tematem (Tabela 18).

Tabela 18. Źródła wiedzy na temat raka szyjki macicy i profilaktyki w opinii badanych.

\begin{tabular}{|c|c|c|c|c|c|c|c|c|c|c|}
\hline \multicolumn{2}{|c|}{ Pyt. Skąd czerpie Pani wiedzę na temat raka szyjki macicy?/profilaktyki? } \\
\hline \multicolumn{2}{|c|}{ Razem } & \multicolumn{2}{c|}{$\begin{array}{c}\text { Poniżej } \\
20\end{array}$} & \multicolumn{2}{c|}{$21-30$} & $31-40$ & $41-50$ \\
\cline { 2 - 12 } & $\mathrm{N}$ & $\%$ & $\mathrm{~N}$ & $\%$ & $\mathrm{~N}$ & $\%$ & $\mathrm{~N}$ & $\%$ & $\mathrm{~N}$ & $\%$ \\
\hline Lekarz ginekolog & 33 & 25 & 0 & 0 & 0 & 0 & 17 & 49 & 14 & 44 \\
\hline Położna & 2 & 1 & 2 & 1 & 0 & 0 & 0 & 0 & 0 & 0 \\
\hline $\begin{array}{c}\text { We własnym } \\
\text { zakresie }\end{array}$ & 70 & 52 & 24 & 58 & 16 & 80 & 16 & 46 & 14 & 44 \\
\hline Nie interesuje się & 30 & 22 & 20 & 41 & 4 & 20 & 2 & 5 & 4 & 12 \\
tym & & & & & & & & & & \\
\hline
\end{tabular}

Źródło: wyniki badań własnych

\section{Dyskusja}

Rak szyjki macicy stanowi około 6,5\% wszystkich zachorowań na nowotwory złośliwe wśród polskich kobiet; jest szóstym rakiem, co do czystości zachorowań, ósmym co do częstości zgonów. Większość zmian przedrakowych występuje w wieku 20-34 lat, rak inwazyjny dotyczy kobiet w wieku 40-50 lat. Jego typy onkogenne to 16 i 18. Postać przedinwazyjna nie daje objawów dlatego ważne jest wykonywanie badań ginekologicznych w połączeniu z cytodiagnostyką w różnych odstępach czasowych. Dzięki temu można szybko wykryć 
patologie i zacząć odpowiednie leczenie. Leczenie stanów przedrakowych i raka szyjki macicy jest skuteczne w zależności od stopnia zawansowania choroby. Zakażenie wirusem brodawczaka ludzkiego (HPV) ma główne znaczenie w rozwoju raka szyjki macicy [5]. Palenie papierosów, stosowanie doustnej antykoncepcji, duża ilość porodów oraz inne choroby przenoszone drogą płciową sprzyjają wystąpieniu infekcji wirusem HPV. Wczesne rozpoczęcie współżycia, duża ilość partnerów seksualnych jest kolejnym czynnikiem, który może spowodować rozwój raka szyjki macicy. Stany zapalne np. upławy przypominają wczesne objawy choroby. Cytologia $\mathrm{w}$ połączeniu ze szczepionką przeciwko wirusowi HPV pozwala uniknąć śmiertelnego zagrożenia. Badania profilaktyczne są najbardziej skuteczną metodą wykrywającą patologie zachodzące w organizmie kobiety [6]. W celu rozpoznania zmian nowotworowych należy wykonać cytologię, następnie kolonoskopię i biopsję celowaną [3].

Edukacja zdrowotna ma ogromne znaczenie w profilaktyce raka szyjki macicy. Zmierza ona do wczesnego wykrycia choroby, uzyskania informacji na temat stanu zdrowia i podjęcia wczesnych działań leczniczo- terapeutycznych. Zachowania zdrowotne wpływają na aktualny stan zdrowia i stanowią istotne ogniwo stylu życia [3].

\section{Wnioski}

- $\quad$ Stan wiedzy na temat raka szyjki macicy jest najniższy jest w grupie kobiet poniżej 20 roku życia.

- $\quad$ Stosunkowo niski odsetek kobiet (zaledwie $42 \%$ poddaje się profilaktycznym badaniom szyjki macicy, co stwarza ryzyko poważnych konsekwencji zdrowotnych.

- Na podstawie przeprowadzonych badań stwierdzono, że stan wiedzy na temat raka szyjki macicy jest niezadawalający.

\section{Zalecenia dla praktyki pielęgniarskiej}

1. Z uwagi na niski poziom wiedzy młodych kobiet nt. profilaktyki raka szyjki macicy konieczne jest objęcie tej grupy intensywnymi 
działaniami z zakresu edukacji zdrowotnej.

2. Tematyka związana $\mathrm{z}$ profilaktyką raka szyjki macicy powinna być popularyzowana $\mathrm{w}$ mediach, $\mathrm{w}$ czasie spotkań $\mathrm{z}$ młodzieżą szkolną.

3. Niezbędne jest zachęcanie rodziców do stosowania szczepień przeciwko wirusowi brodawczaka ludzkiego wobec dziewczynek w kontekście zmniejszenia ryzyka zachorowania na raka szyjki macicy w dorosłym życiu.

\section{Bibliografia/Bibliography:}

1. Sawaryn D., Wróbel A. Poziom wiedzy młodych dziewcząt na temat raka szyjki macicy. Medycyna Rodzinna. 2011;2:35-42.

2. Jeziorski A., Kordek R., i wsp. Onkologia. Podręcznik dla pielęgniarek. Warszawa lat: Wydawnictwo Lekarskie PZWL, 2015.

3. Podolska M., Kozłowska U. Edukacja zdrowotna i świadomość zdrowotna w profilaktyce raka szyjki macicy. Psychoonkologia.2013;(2):71-78.

4. Wronkowski Z., Brużniewicz Sz. Rak szyjki macicy. Polski Komitet Zwalczania Raka. Warszawa. Wydawnictwo Lekarskie PZWL,2008.

5. Nowicki A., Borowa I., Maruszak M. Zachowania zdrowotne kobiet w zakresie zapobiegania, wczesnego wykrywania stanów przedrakowych i raka szyjki macicy. Ginekologia Polska. 2008;(12):840-849.

6. Antos E., Łyszkowska A. Rak szyjki macicy - nigdy dość o profilaktyce i diagnostyce. Magazyn Pielęgniarki i Położnej. 2014;1-2:46-48.

7. Baran W., Kornacka K., Szela S. Ocena wiedzy kobiet z Podkarpacia na temat profilaktyki raka szyjki macicy. Wydawnictwo UR. 2013;(3):311318. 